\title{
Incorporating Sustainability into the Civil Engineering curriculum via cross course collaborations
}

\author{
Claire L. Antaya, Arizona State University \\ Dr. Melissa M. Bilec, University of Pittsburgh \\ Dr. Piervincenzo Rizzo, University of Pittsburgh
}

Dr. Piervincenzo Rizzo earned his Laurea-M.S. equivalent-in Aeronautical Engineering at the University of Palermo, Italy in 1998. After serving in the Italian Army Corps of Engineering, Dr. Rizzo moved to the U.S.A. where he earned a master's degree in 2002 and a Ph.D. in 2004 in Structural Engineering at the University of California at San Diego. In September 2006 he became an assistant professor at the Department of Civil and Environmental Engineering at the University of Pittsburgh and promoted to associate professor with tenure in 2012. Dr. Rizzo's research interests are in nondestructive evaluation and structural health monitoring using techniques such as ultrasound, acoustic emission, thermography, solitary waves, and electromechanical impedance. His current and past researches have been supported by the Pennsylvania Department of Transportation, the National Science Foundation, the American Society for Nondestructive Testing, and various Pitt's seed funding mechanism. He is the recipient of the 2002 Fellowship Research Award and the 2007 Faculty Grant Award from the American Society for Nondestructive Testing, and the 2012 Achenbach Medal, created to recognize a young individual making an outstanding contribution to the advancement of the field of Structural Health Monitoring. Dr. Rizzo is the author of seven book chapters, 53 peer-reviewed journal papers, and more than 120 conference papers and presentations.

Prof. Amy E. Landis, Arizona State University 


\title{
Incorporating Sustainability into the Civil Engineering curriculum via cross course collaborations
}

\begin{abstract}
Civil engineers play a significant role in designing, constructing, and maintaining systems. Concepts of sustainability are critical components to civil engineers' education. Professors at the University of Pittsburgh (UPitt) and Arizona State University (ASU) have collaborated to integrate sustainability into the Civil Engineering curriculum in two manners; first, via target sustainability units and/or labs that are integrated into traditional courses and second, via the creation of new courses whose foci are on sustainability. We present and discuss the development and value in understanding student perceptions of sustainability through two sustainability labs, Infrared Thermography (IRT) Energy Audit Lab and Sustainable Materials Design Lab, and their implementation into three collaborative courses, Introduction to Nondestructive Evaluation and Structural Health Monitoring (NDE), Design for the Environment (DfE), and Green Buildings: Design and Construction (GB), that have been designed to enhance the learning of sustainability concepts. Pre- and post-assessment surveys were administered to assess changes in student perceptions of sustainability concepts and applications over a four-year period. Survey results present changes in perceptions of sustainability concepts and applications over time as a result of the active and experiential learning units and classes. The concurrent teaching of these sustainability units and classes at UPitt and ASU enhanced student collaboration within and across universities, reinforcing the potential for future cross-course, multi-university active and experiential learning partnerships.
\end{abstract}

Introduction

As concerns of global climate change and energy independence increases, the next generation of civil engineering students will need to be prepared to solve complex sustainability challenges. Since green technology is emerging as the most important industry of the $21^{\text {st }}$ century ${ }^{1}$, it is critical that students are provided the opportunity to understand the linkage between their decisions, engineering, and sustainability. Engineering education can provide students with the tools to approach the complex problems of the $21^{\text {st }}$ century while considering these aspects, which are key for designing sustainable systems ${ }^{2}$. Many programs around the nation are incorporating sustainability into their curriculum.

The National Research Council (NRC) notes several challenges to effective undergraduate education in science, technology, engineering, and mathematics (STEM) disciplines. These challenges include providing engaging laboratory, classroom and field experiences; teaching large numbers of students from diverse backgrounds; improving assessment of learning outcomes; and informing science faculty about research on effective teaching ${ }^{3-5}$. Research suggests that team based projects can also enhance student learning in STEM fields since it promotes active and collaborative learning while simultaneously promotes individual accountability, personal responsibility, and communication skills ${ }^{2}$. In addition several Accreditation Board for Engineering Technology (ABET) criteria require engineering programs to demonstrate that students attain the ability to function collaboratively and communicate effectively. 
Many researchers agree that, in order for engineers to be able to approach and solve sustainability-related problems, their education needs to allow for interactions and diversity; aspects that experiential learning approaches involve. Experiential learning involves constructing meaning from direct experience and actively involves the learner in a real (rather than abstract) experience $^{6,7}$.

Three civil engineering courses, Introduction to Nondestructive Evaluation and Structural Health Monitoring (NDE), Design for the Environment (DfE), and Green Buildings: Design and Construction (GB) at the University of Pittsburgh (UPitt) along with one course at Arizona State University (ASU), Design for the Environment (DfE), have collaborated to develop and incorporate active, experiential learning activities that enhance the learning of sustainability concepts. One of the merits of creating cross-course activities in engineering education is that enrolled in a traditional civil engineering course (e.g. from NDE) that would never have been exposed to concepts of sustainability have hands-on, active interaction with these concepts and students in the sustainability track (e.g. from DfE and GB) are afforded the opportunity to learn the technological aspects of operating traditional civil engineering tools.

The goal of this cross-course collaboration experience is to enrich and expand student experience from and exposure to sustainability concepts in the different civil engineering classrooms. This paper discusses the development and value in understanding student perceptions of sustainability from the incorporation of two novel sustainability labs over a four-year period two courses taught at UPitt and one course taught at ASU as gauged by changes in the perceptions of sustainability concepts and the application of sustainability with the use of civil engineering tools via pre- and post-assessment surveys. These surveys examine the value of the active and experiential activities employed in the civil engineering classroom.

\section{Methods}

Two sustainability labs that employ experiential learning were developed by the authors and evaluated from 2009-2012. These labs were taught in three civil engineering courses at UPitt: Introduction to Nondestructive Evaluation and Structural Health Monitoring (NDE), Design for the Environment (DfE), and Green Buildings: Design and Construction (GB) and in one course at ASU, Design for the Environment (DfE), for approximately 400 students in total. Figures 1 and 2 illustrate the approach and timeline of events for the development and implementation of these labs. Below are descriptions of the labs and assessment methods. 


\section{Development of Experiential and Active Sustainability Learning Labs}

\begin{tabular}{|c|c|c|}
\hline Infrared & \multicolumn{2}{|c|}{ Deployment of Labs within Civil Courses at UPitt and ASU } \\
\hline $\begin{array}{l}\text { graphy } \\
\text { (IRT) }\end{array}$ & $\begin{array}{l}\text { UPitt Design for the } \\
\text { Environment (DfE) }\end{array}$ & Pre- and Post- Assessment Survey \\
\hline $\begin{array}{l}\text { Home } \\
\text { Energy } \\
\text { Audit Lab }\end{array}$ & $\begin{array}{l}\text { UPitt Green Buildings: } \\
\text { Design and } \\
\text { Construction (GB) }\end{array}$ & $\begin{array}{l}\text { 1. "Which of the following careers would } \\
\text { integrate concepts of sustainability and } \\
\text { design for the environment?" }\end{array}$ \\
\hline $\begin{array}{l}\text { Sustain- } \\
\text { able }\end{array}$ & $\begin{array}{l}\text { UPitt Introduction to } \\
\text { Nondestructive } \\
\text { Evaluation and } \\
\text { Structural Health }\end{array}$ & $\begin{array}{l}\text { 2. "Which of the following sustainability } \\
\text { issues need engineering in order to } \\
\text { arrive at a solution?" }\end{array}$ \\
\hline Materials & Monitoring (NDE) & 3. "I have heard of the following uses of \\
\hline $\begin{array}{l}\text { Design } \\
\text { Lab }\end{array}$ & $\begin{array}{l}\text { ASU Design for the } \\
\text { Environment (DfE) }\end{array}$ & \\
\hline
\end{tabular}

Figure 1. Development of two experiential and active sustainability-learning labs. This figure illustrates the labs deployed in three courses at UPitt and one course at ASU assessed with three pre- and post-survey questions.

\begin{tabular}{|c|c|c|c|c|c|}
\hline \multicolumn{6}{|c|}{ Sample of Developed \& Incorporated Sustainability Labs Timeline } \\
\hline & Course & 2009 & 2010 & 2011 & 2012 \\
\hline \multirow{3}{*}{ UPitt } & DfE & IRT Energy Audit & IRT Energy Audit & $\begin{array}{c}\text { IRT Energy Audit } \\
\text { Green Labels }\end{array}$ & $\begin{array}{l}\text { Watt Meter Audit } \\
\text { IRT Energy Audit } \\
\text { Green Labels }\end{array}$ \\
\hline & GB & GB Site Visit & $\begin{array}{l}\text { GB Site Visit } \\
\text { IRT Materials }\end{array}$ & $\begin{array}{l}\text { GB Site Visit } \\
\text { IRT Materials }\end{array}$ & $\begin{array}{l}\text { GB Site Visit } \\
\text { IRT Materials }\end{array}$ \\
\hline & NDE & IRT Energy Audit & IRT Energy Audit & $\begin{array}{l}\text { IRT Energy Audit } \\
\text { IRT Materials }\end{array}$ & $\begin{array}{l}\text { IRT Energy Audit } \\
\text { IRT Materials }\end{array}$ \\
\hline ASU & DfE & & & & $\begin{array}{l}\text { Watt Meter Audit } \\
\text { IRT Energy Audit } \\
\text { Green Labels }\end{array}$ \\
\hline
\end{tabular}

Figure 2. Sample of developed and incorporated sustainability labs. This figure depicts the timeline of events for the implementation of these labs in in three courses at UPitt and one course at ASU assessed with three pre- and postsurvey questions.

Description of the infrared thermography (IRT) energy audit lab

The IRT Energy Audit Lab was designed to enhance existing activities within the traditional civil engineering course, NDE, and a new civil engineering course, DfE. Dr. Rizzo (NDE instructor) collaborated with Drs. Landis (DfE) and Bilec (DfE), to create and teach the IRT lab in both the 
NDE and DfE classes. NDE traditionally utilizes noninvasive methodology for evaluating the health of existing structures. Inspection techniques for diagnosing energy concerns within structures are traditionally qualitative and rely heavily on surface observations. Teams of students conduct a traditional energy audit within this course by inspecting a structure through the lens of both a regular digital camera and an IRT camera. Energy audit reports generated by the students contain a description of the inspection procedure, the settings of the cameras utilized during inspection and the structural diagnosis in a qualitative format. The IRT Energy Audit Lab enhances existing energy audits, traditionally conducted within NDE, and expands this lab to apply to both the NDE and DfE courses, where the built environment is closely examined.

Learning objectives and associated Bloom's levels of intellectual behavior ${ }^{9}$ for the IRT Energy Audit Lab are listed in Table 1. Teams of students conducted an energy audit of an existing structure by utilizing an IRT camera in addition to a regular digital camera. In the energy audit lab assignment, shown in Figure 3, students utilized temperature information generated by the IRT camera and calculated the potential building's energy losses for the area(s) depicted in the camera images. Students took this quantitative approach one step further and calculated the total annual costs of these energy losses, suggested an energy efficient solution for this structure, such as improved insulation or window replacement, and calculated the total energy and cost savings for their proposed solution. Students presented the results of their IRT Energy Audit Lab through an industry report format. The IRT camera used for NDE applications further generated a proposed algorithm for assessing IRT images post-application of this technology ${ }^{10}$. This lab was adopted and implemented in new civil engineering courses, DfE and GB, as an experiential learning activity for exploring energy usages of the built environment.

Table 1. IRT Energy Audit Lab Learning Objectives and Bloom's Levels of Intellectual Behavior

\begin{tabular}{|c|c|c|c|c|c|c|}
\hline \multirow{2}{*}{$\begin{array}{c}\text { Infrared Thermography (IRT) Energy Audit Lab } \\
\text { Learning Objectives } \\
\text { The aim of this lab is for students to have a hands-on, active interaction } \\
\text { with concepts of sustainability and energy via experience conducting } \\
\text { an energy audit with an IRT camera }\end{array}$} & \multicolumn{6}{|c|}{$\begin{array}{l}\text { Bloom's Levels of } \\
\text { Intellectual Behavior }\end{array}$} \\
\hline & $\begin{array}{l}0 \\
00 \\
0 \\
0 \\
0 \\
0 \\
\Xi\end{array}$ & 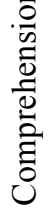 & 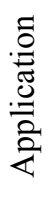 & 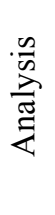 & 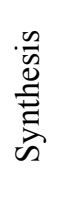 & 音 \\
\hline $\begin{array}{l}\text { to become comfortable with the use of an Infrared camera and be able to } \\
\text { interpret the images produced }\end{array}$ & $\mathrm{X}$ & $\mathrm{X}$ & $\mathrm{X}$ & & & \\
\hline $\begin{array}{l}\text { to utilize the Infrared camera to perform a small scale "energy audit" of one } \\
\text { group member's apartment }\end{array}$ & & & $\mathrm{X}$ & $\mathrm{X}$ & & \\
\hline to estimate the heat loss through an exterior wall section in the apartment & & & $\mathrm{X}$ & & & \\
\hline $\begin{array}{l}\text { to identify an area of imperfection through Infrared examination and estimate its } \\
\text { effects on heat loss }\end{array}$ & & & & $\mathrm{X}$ & $\mathrm{X}$ & \\
\hline $\begin{array}{l}\text { to suggest an improvement to the area of imperfection and calculate the energy } \\
\text { savings that could be realized through implementing the improvement }\end{array}$ & & & & $\mathrm{X}$ & $\mathrm{X}$ & $\mathrm{X}$ \\
\hline
\end{tabular}




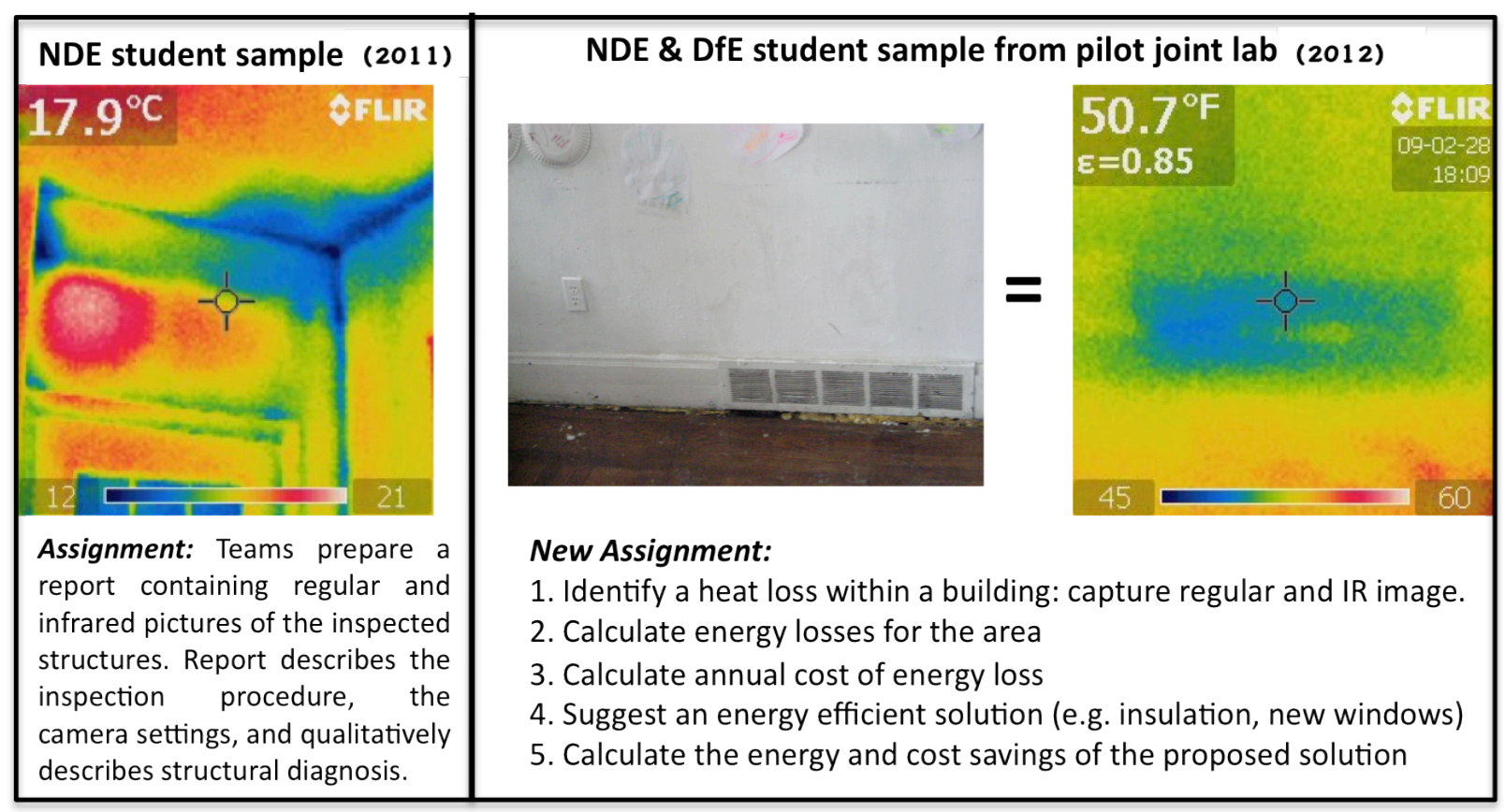

Figure 3. IRT Cross-course Lab. Example of house survey by means of an infrared camera; taken from NDE 2011 and NDE/DfE 2012 student reports. Left to right: Exterior kitchen wall; Wall section where students calculated energy loss from the vent in 2012. The temperature on top left of each figure is the temperature associated with the center of the IR's view-finder.

\section{Description of the sustainable materials design lab}

The Sustainable Materials Design (SMD) Lab was created to introduce design for disassembly and design for the environment concepts through an active and experiential learning activity within the DfE course. This lab was easily adoptable within the NDE and GB courses, as both reference the evaluation of products and processes. DfE focuses on student comprehension of the Triple Bottom Line, society, economics, and the environment, as they relate to decisions in product and process designs ${ }^{11}$. The SMD Lab is dynamic mix of design evolution discussions, research of environmental product declarations (EPDs) and hands-on experiments to actively experience design progression. Learning objectives for this lab are listed in Table 2.

Teams of students were tasked with a timed competition to disassemble and reassemble their designated office chair. Chairs were representative of design evolution and included a 1950's chair, early 1990's chair, late 1990's chair and a 2000's chair that was advertised as 'green' based on its ease of disassembly and materials (Figure 4). Students compiled the data that they collected for both disassembly and reassembly times as well as other metrics representing design for disassembly and design for materials selection such as number of parts, number of tools used, number of materials used in the chairs, and recyclability of parts for each chair. Students were asked to evaluate the sustainability of the different chairs based on the metrics and data collected in lab report format. Students synthesized and evaluated the chair designs within their reports based on design evolution discussions in class, previous research conducted on EPDs and their experience with disassembling and reassembling their chair during the lab. 
Table 2. Sustainable Materials Design Lab Learning Objectives and Bloom's Levels of Intellectual Behavior

\section{Sustainable Materials Design Lab}

Bloom's Levels of

\section{Learning Objectives}

The aim of this lab is for students to have a hands-on, active interaction with concepts of sustainability and apply design for the environment principles to product and process designs

to explain the basics of design evolution

to apply design evolution concepts to analyze the office chairs from recent eras in terms of their "green" quality, or design for the environment to determine the feasibility of end-of-life recycling of the materials comprising the chair via disassembly, material categorizing and weighing to interpret ease of disassembly, part separability, and clarity of the appropriate recycling stream with respect to the chair assigned to our group and the designated "green" chair

\section{Intellectual Behavior}

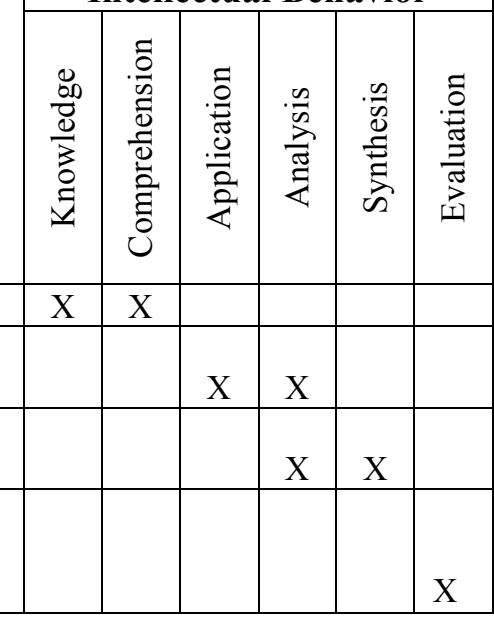

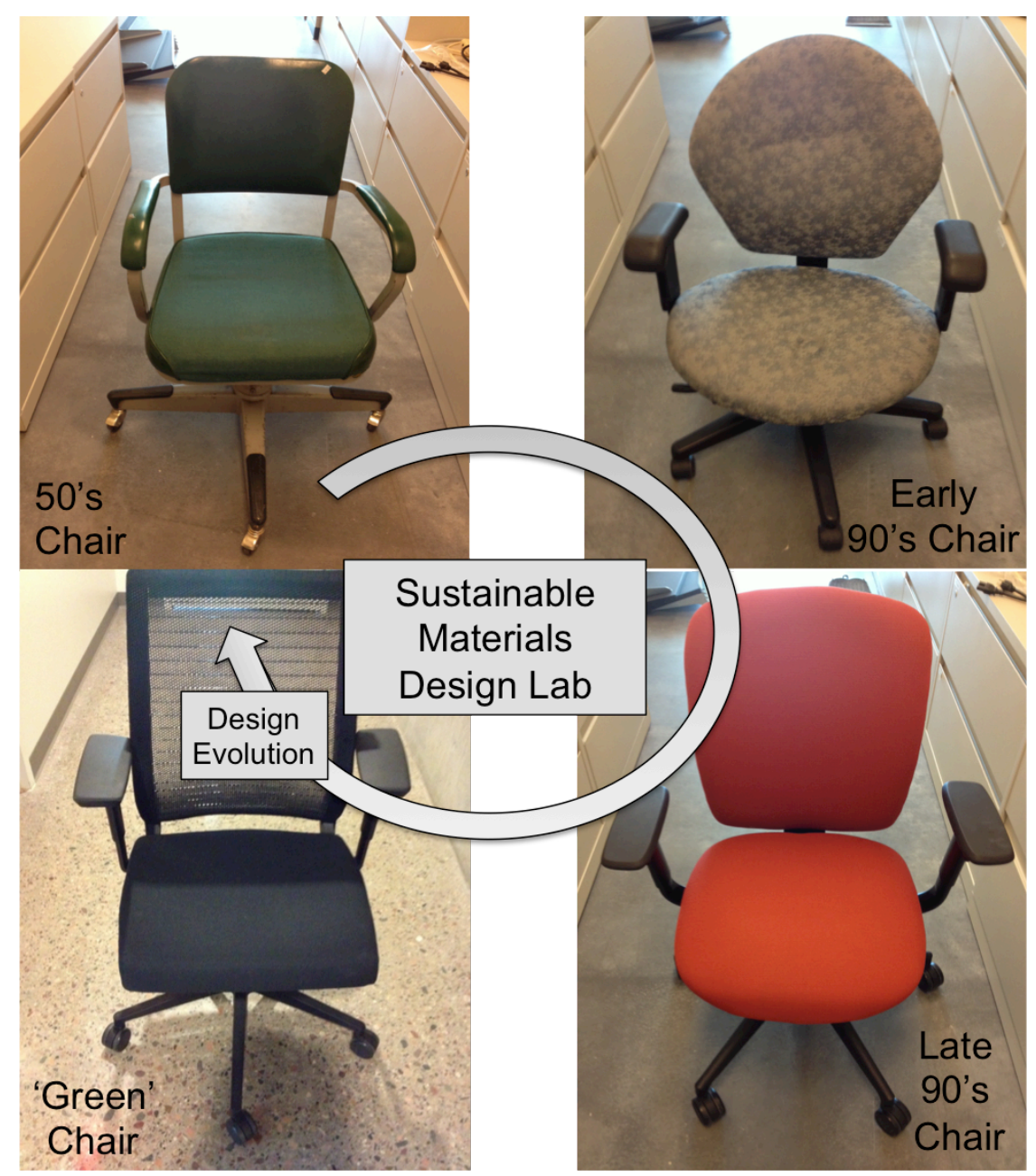

Figure 4. Sustainable Materials Design Cross-course Lab. Example of chair disassembly by means of common household tools. Top left to right: 1950's office chair; early 1990's office chair. Bottom left to right: 2000's 'green' office chair; late 1990's office chair. 
Assessments

Student perceptions of sustainability concepts and applications were measured through pre- and post-assessment surveys. This survey research was approved exempt under IRB protocol \# PRO10010207 at The University of Pittsburgh and \#1206007924 at Arizona State University. These pre- and post- assessment surveys were administered in all three courses, NDE, DfE, and $\mathrm{GB}$, for a period of four years from 2009-2012. Formative, pre-assessment surveys were employed to collect information regarding students' preconceptions and/or previous knowledge of careers that integrate concepts of sustainability as well as sustainability applications of the IRT camera. Students took this formative assessment prior to being exposed to course material. The question students responded to was: "which of the following careers would integrate concepts of sustainability and design for the environment?" and responses included "engineering consulting", "construction manager", "government position", "researcher", "teacher", "health care professional", "marketing/sales", "none of the above". The question format was "select all that apply."

Summative, post-assessment surveys were utilized to collect data regarding knowledge of careers that integrate concepts of sustainability as well as sustainability applications of the IRT camera, in the same order as they were presented in the formative assessment survey. Students took the summative assessment survey after completing the final class of the semester for each course. The question students responded to was: "I have heard of the following uses of an infrared camera" and responses included "evaluating material strength", "quantifying temperature differences", "measuring vehicle (or object) speed", "searching for abnormalities in body tissue", "viewing activities through building walls", "identifying energy losses in buildings", "evaluating green building products for energy efficiency" and "none of the above." The question format was "select all that apply."

\section{Results and Discussion}

The pre- and post-assessment survey data is presented in Figures 5-9. Figures 5 and 6 depict preand post-survey assessment results regarding which careers students perceive integrate concepts of sustainability. Figures 7 and 8 illustrate pre-and post-survey results respectively, regarding knowledge of sustainability applications for the IRT camera. The IRT camera application for pre- and post-survey assessment results is highlighted in the 2012 DfE courses at ASU and UPitt in Figure 9. 


\section{Student Perceptions of Careers That Integrate Sustainability}

Concepts 2009-2012

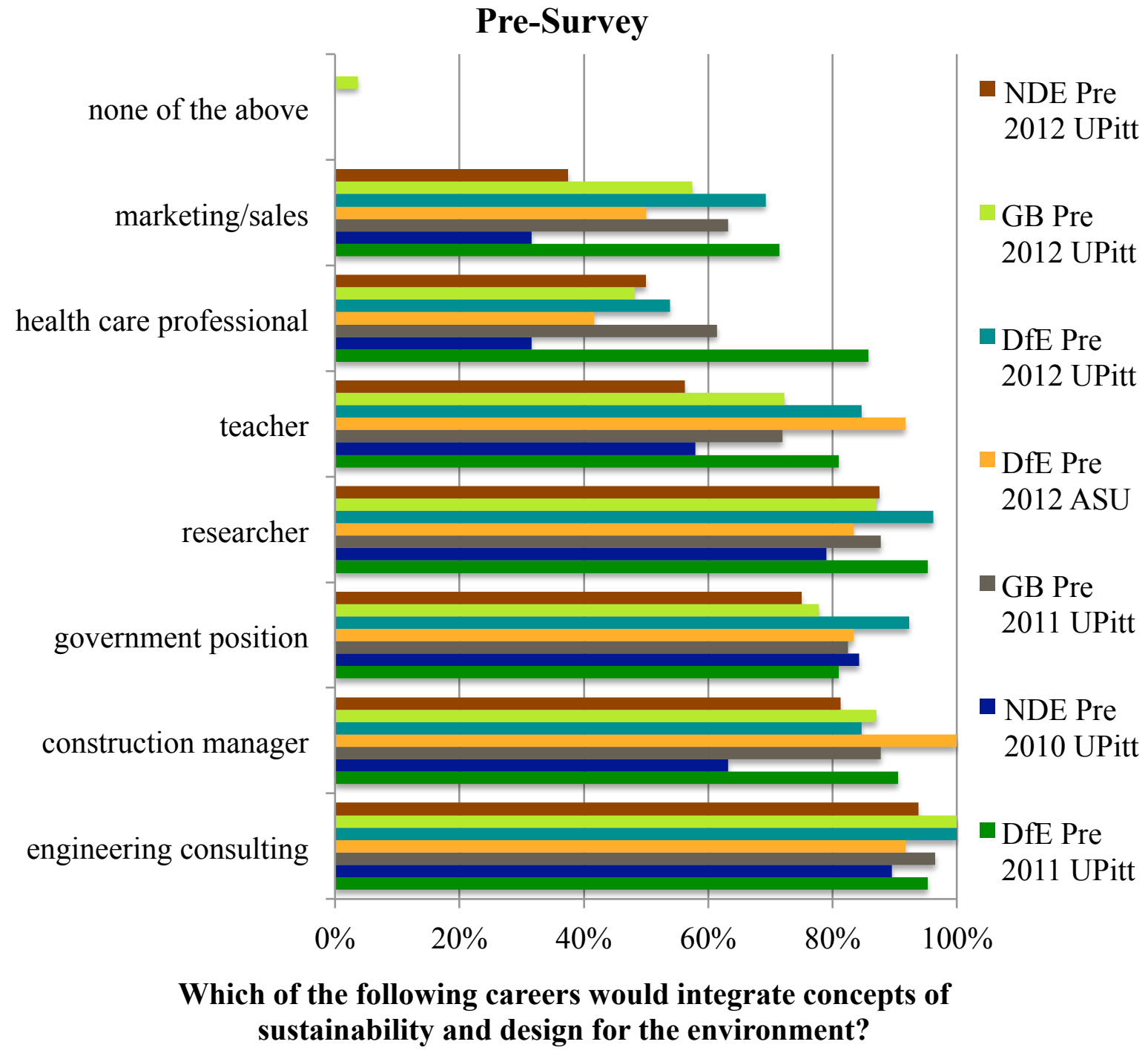

Figure 5. Student Perceptions of Careers That Integrate Sustainability Concepts 2009-2012 depicts student respondents' answers for careers that integrate concepts of sustainability from pre-assessment surveys. 


\section{Student Perceptions of Careers That Integrate Sustainability Concepts 2009-2012 Post-Survey}

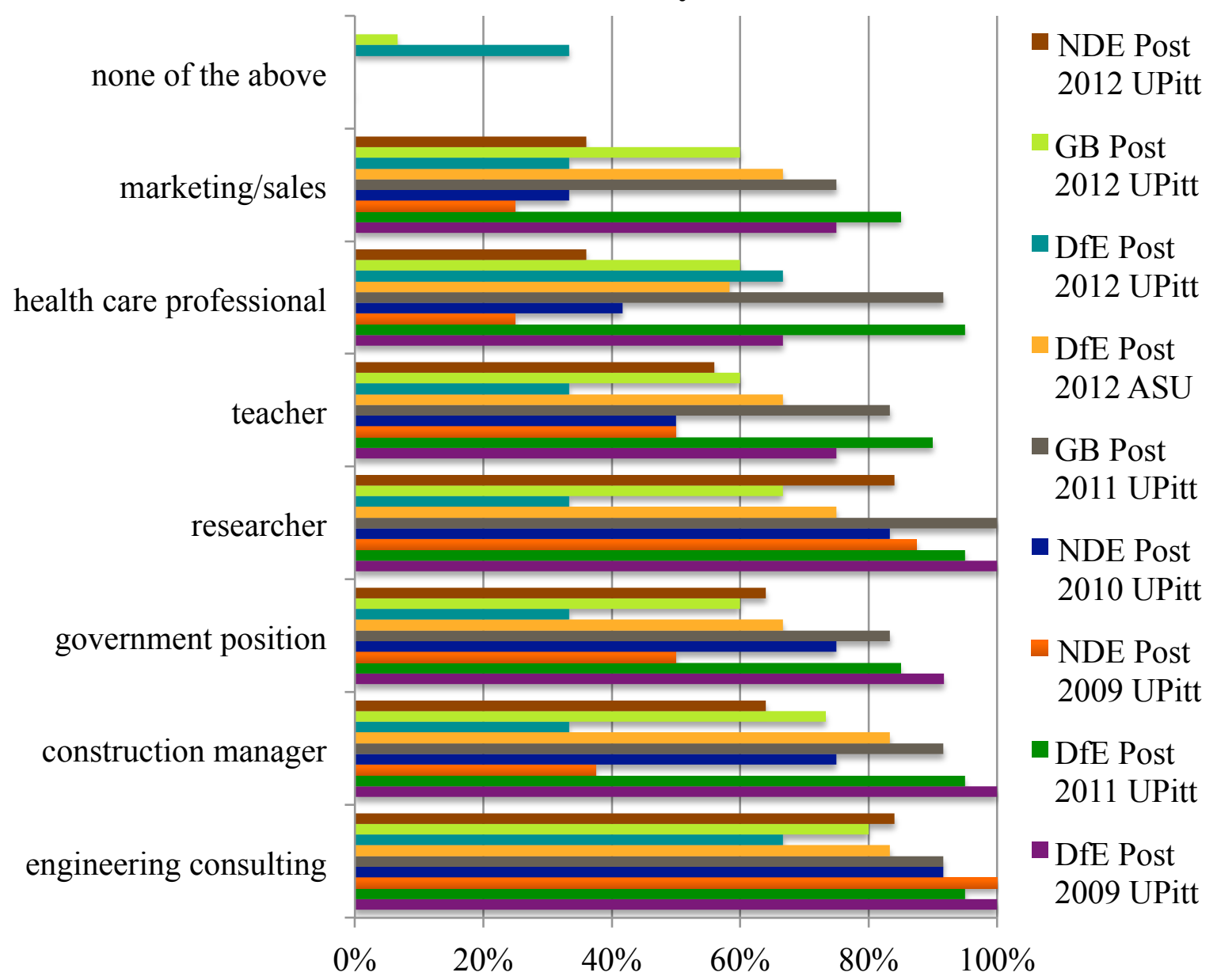

\section{Which of the following careers would integrate concepts of sustainability and design for the environment?}

Figure 6. Student Perceptions of Careers That Integrate Sustainability Concepts 2009-2012 depicts student respondents' answers for careers that integrate concepts of sustainability from post-assessment surveys.

After participating in the DfE, NDE, and GB courses utilizing active and experiential learning labs, students showed changes in their perceptions of sustainability concepts and applications. The results of the survey in Figures 5 and 6 are presented over a four-year period for three different classes, where DfE was taught via distance learning at ASU and UPitt in 2012. Response rates for all of the surveys were higher than $80 \%$. The results showed students have the perception that engineers in consulting, researchers and construction managers are the three predominant careers that integrate concepts of sustainability. These are also the career paths the majority of the students taking these courses will choose to follow, thus results may be influenced due to greater interest in these careers than others. Greater than or equal to $50 \%$ of respondents over the four-year period believe that government careers integrate concepts of sustainability. This trend follows for teachers, with the exception of DfE Post 2012 at ASU. 
Careers in healthcare and marketing/sales fluctuated to the largest degree over the administration of the surveys. In 2011 healthcare sustainability topics were added as a semester project within DfE. The increase in healthcare career awareness may be reflected by a result of this inclusion. The authors acknowledge that the decrease in perceptions of careers that integrate sustainability may be a reflection on the way in which the material was presented to the students. The instructors required students to think critically about the inclusion of sustainability concepts in careers. The decrease may have resulted from students' perceived notion that even though the careers seem to integrate concepts of sustainability prior to the class, the time in which the persurvey was taken, the careers in fact integrate sustainability intermixed with green washing. Thus, the presentation of class material may have impacted the way in which students perceived the careers post-class and post-survey their perceptions decreased. The authors recognize that in future analysis, additional survey questions will be added to assess the direct impact on the lab activity.

\section{Student Perceptions of Sustainability Applications for IRT} Camera 2009-2012

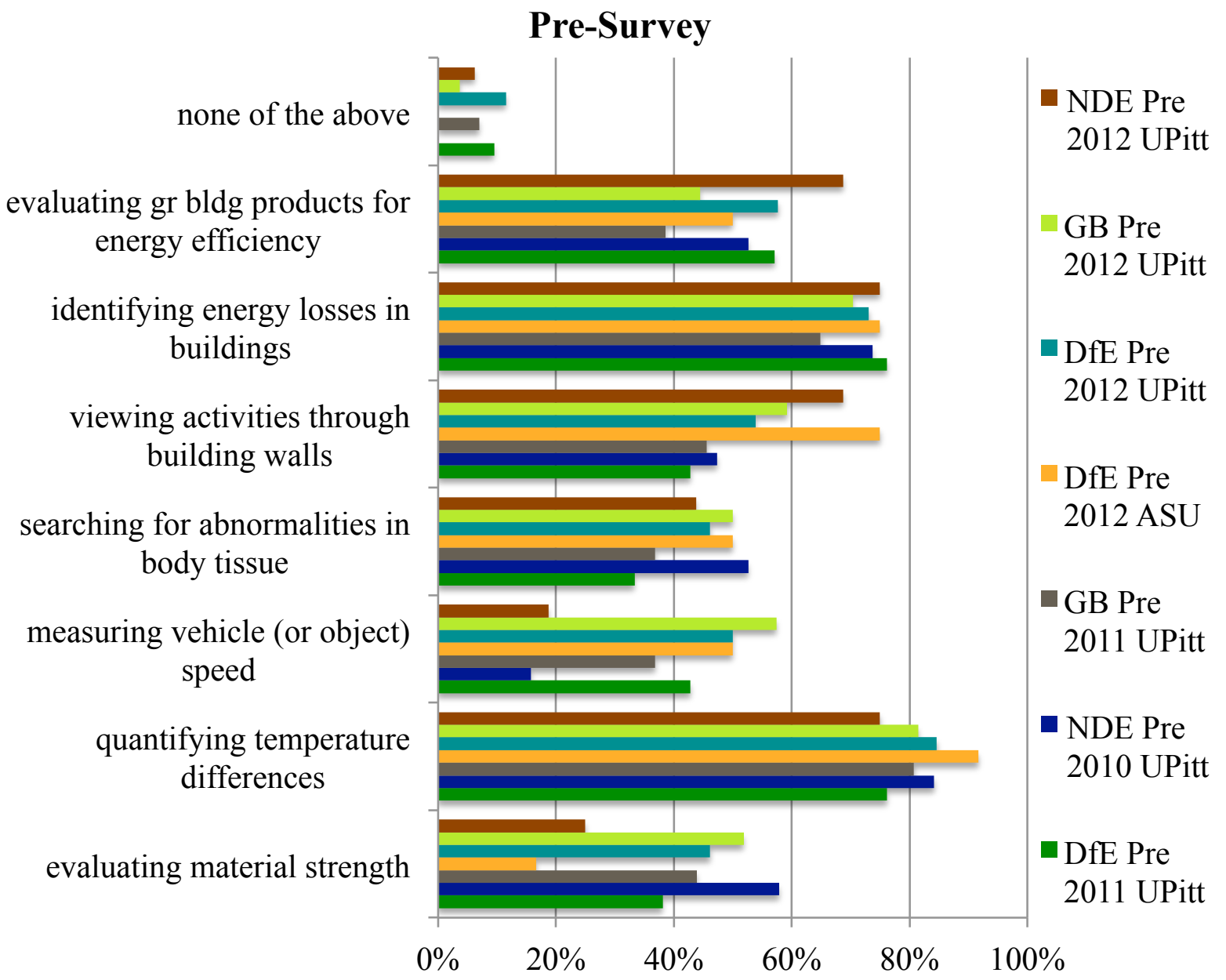

I have heard of the following uses of an infrared camera

Figure 7. Student Perceptions of Sustainability Applications for IRT Camera illustrates student respondents' answers regarding knowledge of sustainability applications for the IRT camera from pre-assessment surveys. 


\section{Student Perceptions of Sustainability Applications for IRT \\ Camera 2009-2012 \\ Post-Survey}

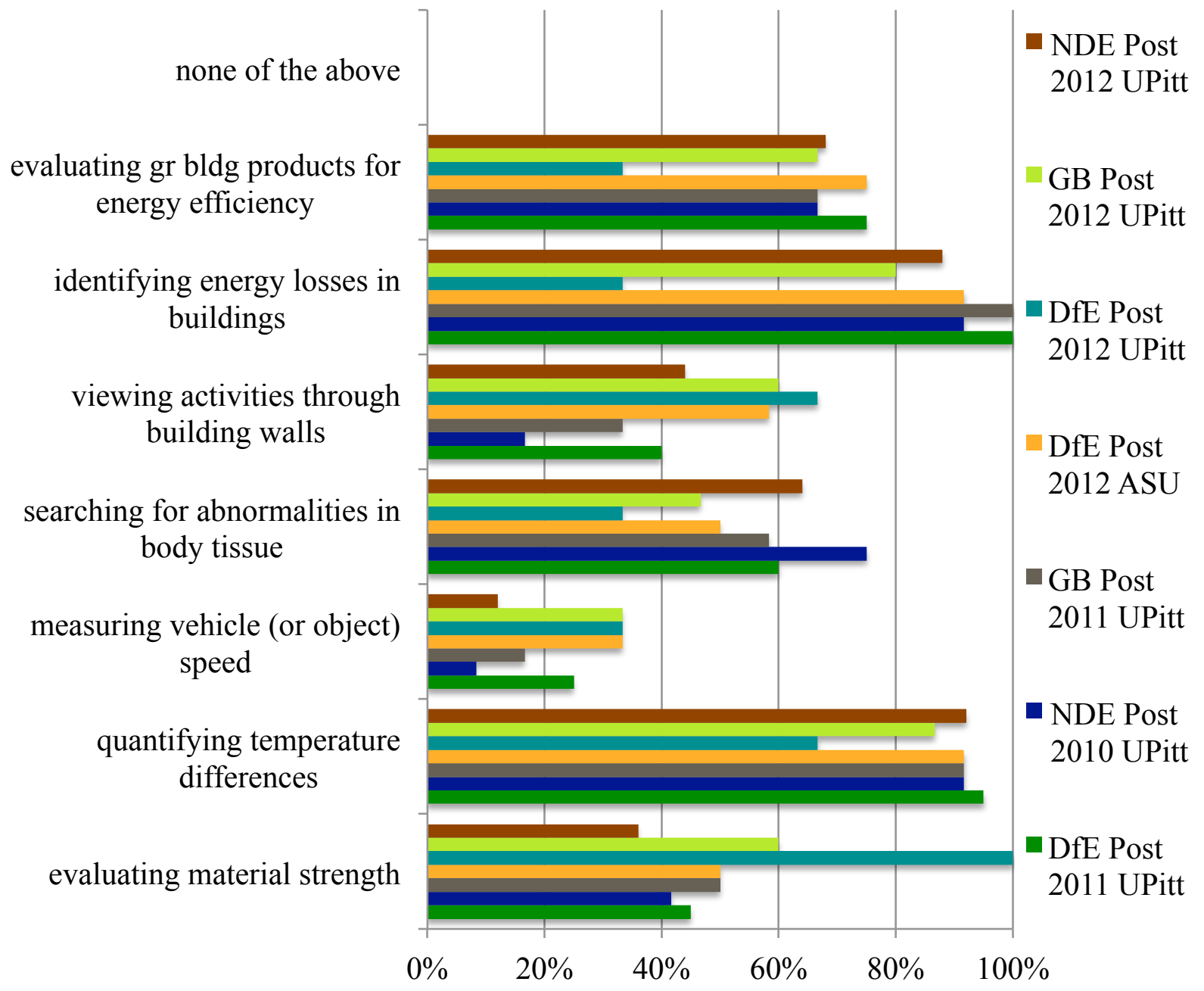

I have heard of the following uses of an infrared camera

Figure 8. Student Perceptions of Sustainability Applications for IRT Camera illustrates student respondents' answers regarding knowledge of sustainability applications for the IRT camera from post-assessment surveys.

One of the major cross-course activities was the IRT Energy Audit Lab, and the survey shows that students are learning the sustainability applications of IRT camera (Figures 7 and 8). Students tend to increase their perceptions of sustainability-related applications for the IRT camera after taking the courses. The perception students have both pre- and post-survey was that IRT cameras have a wide range of applications both within civil engineering and within other disciplines. Students select quantifying temperature differences, identifying energy losses in buildings and evaluating greater building products for energy efficiency as the top three sustainability applications for an IRT camera. Prior to the implementation of this lab, sustainability was not taught in NDE and students in DfE and GB were not exposed to the IRT camera tool. This is reflected in the "none of the above" awareness prior to exposure to course material, two courses of DfE and two courses of GB. 


\section{Student Perceptions of Sustainability Applications for IRT CameraASU and UPitt in DfE 2012}

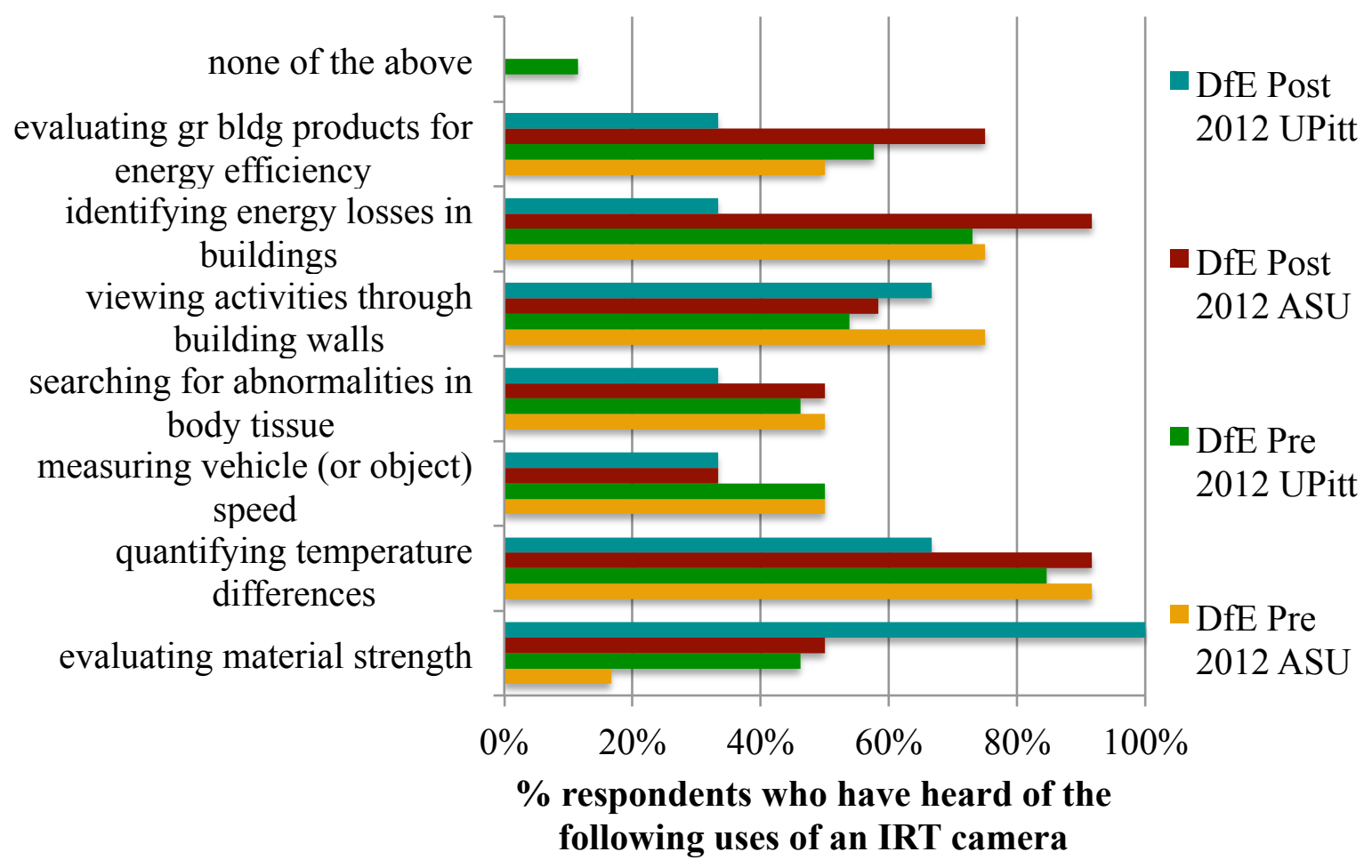

Figure 9. Student Perceptions of Sustainability Applications for IRT Camera at ASU and UPitt in DfE 2012 illustrates student respondents' answers regarding knowledge of sustainability applications for the IRT camera.

In 2012 the IRT Energy Audit Lab was concurrently co-taught within DfE at UPitt and ASU. The findings reflect the survey results from the addition of this lab to the DfE course offering at ASU (Figure 9). ASU student responses for knowledge of IRT camera revealed that prior to taking DfE, students had heard of all 7 uses listed and after taking this course students responded that they had increased awareness for 4 out of 7 uses listed. Viewing activities through building walls, searching for abnormalities in body tissue, and measuring vehicle (or object) speed were the three uses listed for which students remained stable or decreased in awareness. This may be a result of increased exposure to the built environment applications for the IRT camera in comparison to other uses. No ASU students selected "none of the above" as uses for the IRT camera. UPitt student responses for knowledge of IRT camera uses revealed that prior to taking DfE, students had heard of all 7 uses listed, including greater than $10 \%$ of responses having never heard of the listed IRT camera uses. After taking this course students responded that they had increased awareness for 2 out of 7 uses listed, including viewing activities through building walls and evaluating material strength. The origin of this result is unclear, but it may be attributed to coverage of additional uses of the IRT camera when compared to familiar, common uses. 


\section{Conclusion}

The active and experiential lab activities developed for three Civil Engineering courses, NDE, DfE and GB, at ASU and UPitt, reached approximately 400 students of different levels from 2009 to2012. One merit of creating cross-course activities is that students experienced first-hand, know how sustainability concepts and tools that can be applied within their field. On the flip side, students in the sustainability track (e.g. DfE \& GB) had the opportunity to learn the intricate details of how the tools that they use apply to sustainability. The activities also directly addressed many of the issues facing STEM education. The Infrared Thermography (IRT) Energy Audit Lab and Sustainable Materials Design Lab employed experiential learning, which enhances the quality of student learning. Furthermore, gains in tacit knowledge prepared these future engineering professionals to solve complex and multidisciplinary problems in a sustainable and global context through collaborations amongst university students. Pre- and postassessment surveys of the students over four years revealed that awareness of sustainability, careers that integrate sustainability concepts, and knowledge of IRT camera applications increased over time as a result of implementing the two active, experiential learning labs.

\section{Acknowledgements}

The authors would like to acknowledge the National Science Foundation Course Curriculum and Laboratory Improvement Program (CCLI) Type 1- Award No. 0942172/1242325, National Collegiate Inventors and Innovators Alliance (NCIIA) Course and Program Grant Award No. 5120-07, the University of Pittsburgh Innovation in Excellence Award (IEA), and the ASU Gary and Diane Tooker Professorship for Effective Education in STEM for funding this research.

\section{References}

1. Friedman, T. L. (2007). The Power of Green. New York Times Magazine.

2. Allen, D., C. Murphy, et al. (2006). "Sustainable engineering: a model for engineering education in the twentyfirst century?" Clean Technologies and Environmental Policy 8(2): 70-71.

3. Fox, M. A. and N. Hackerman (2003). "Evaluating and Improving Undergraduate Teaching in Science, Technology, Engineering, and Mathematics (Book)." Mathematics Teacher 96(8): 604-604.

4. Donovan, S. and J. Bransford (2005). How Students Learn: History, Mathematics, and Science in the Classroom, \{National Academies Press\}.

5. Bransford, J. D., A. L. Brown, et al. (2006). "How People Learn Brain, Mind, Experience and School (Expanded Version)." Education Canada 46(3): 21-21.

6. Cantor, J. A. (1995). Experiential Learning in Higher Education: Linking Classroom and Community, Association for the Study of Higher Education. ERIC Clearinghouse on Higher Education, Association for the Study of Higher Education.

7. Itin, C. M. (1999). "Reasserting the Philosophy of Experiential Education as a Vehicle for Change in the $21 \mathrm{st}$ Century." The Journal of Experiential Education 22(2): 91-98.

8. Yeo, R. K. (2008). "Brewing service quality in higher education: Characteristics of ingredients that make up the recipe." Quality Assurance in Education 16(3): 266-286.

9. Bloom, B. (1956). Taxonomy of Educational Objectives, Handbook I: The Cognitive Domain. New York: David McKay.

10. Vandone, A., P. Rizzo, et al. (2012). "Two-Stage Automated Defect Recognition Algorithm for the Analysis of Infrared Images." Research in Nondestructive Evaluation 23(2): 69-88. 
11. Torick, D., Bilec, M., Marriott, J., and Landis, A. E. (2009). "Development and Outcomes of a Design for the Environment Course." Proceedings of the $116^{\text {th }}$ American Society for Engineering Education Conference. June 16, 2009, Austin, Texas 